Бородіца С. B. кандидат філологічних наук, доцент Тернопільський національний педагогічний університет імені Володимира Гнатюка

\title{
ОСОБЛИВОСТІ МОДЕЛЮВАННЯ ХУДОЖНЬОГО СВІТУ В ІСТОРИЧНІЙ ПРОЗІ ЮЛІАНА ОПІЛЬСЬКОГО
}

У статті досліджується характер художніх иукань Ю. Опільського в історичній белетристииі початку XX cm., його новаторство у творенні національного історичного роману, зокрема у моделюванні художньої картини світу та образу персонажа у ній, своєрідність історіософського мислення мития в контексті інтелектуальної прози його доби.

Ключові слова: жанр, історична проза, історіософія, модель художнього світу, повість, поетика, роман.

В статье исследуется характер художественных исканий Ю. Опильского в исторической беллетристике начала ХХ cm., его новаторство в создании национального исторического романа, в частности в моделировании художественной картины мира и образа персонажа в ней, своеобразие историософского мыиления художника в контексте интеллектуальной прозы его времени.

Ключевые слова: жанр, историческая проза, историософия, модель художественного мира, повесть, поэтика, роман.

The article investigates the character of artistic searching of Yu. Opilskyy in historical fiction of the beginning of twentieth century. The author deals with the innovation of the writer in the creation of the national historical novel, particularly in modeling of the artistic world view and the image of the character in it, the artist's historiosophical thinking identity in the context of intellectual prose of his day.

Key words: genre, historical prose, model of the art world, story, poetry, novel. 
Ю. Лотман зазначав, що «з одного боку, художня модель світу відображає об'єктивну дійсність у ї̈ найбільш загальних категоріях, а з іншого, - свідчить про авторське світорозуміння» [Лотман 1970: 25]. Тому рецепція особливостей моделювання художнього світу в історичних повістях і романах Ю. Опільського важлива органічна складова розуміння творчої індивідуальності автора, його історіософського мислення, оскільки модель художнього світу прозового твору є концептуальним компонентом вираження світобачення митця, у чому полягає актуальність дослідження.

Світ художнього тексту є соціально, історично та культурно обумовленим. I. Лівенко вважає, що: «Художня модель світу як домінанта поетики визначає основні формально-змістові пріоритети творчості будь-якого митчя, вбираючи в себе ті характеристики типу творчості, які репрезентують світоглядні орієнтири автора в їх художній інтерпретащіï» [Лівенко 2007: 16].

Ю. Опільський - «художник із власним поглядом на історичні постаті і події», якому «доводилось долати традиції» [Ільницький 1994: 4]. Тому вивчення домінантних ознак історичних романів і повістей прозаїка бачиться продуктивним. У цьому контексті вони вирізняються серед тогочасної історичної белетристики В. Будзиновського, Катрі Гриневичевої, Наталени Королевої, Б. Лепкого, А. Лотоцького, О. Назарука, С. Ордівського, А. Чайковського «балястом науковости» та «ерудизмом» (М. Семчишин).

Автор, у першу чергу, шукав адекватну форму, яка б відповідала особливостям історичного матеріалу і задуму письменника. Він намагався створити інтелектуальну історію України, історію ідей, породжених життям українського народу, показати специфіку його суспільно-історичного досвіду. Тому жанр історичного роману за формальною і смисловою структурою органічно відповідав природі письменницького світорозуміння, способу його романного мислення. У Львові 1938 року побачила світ «історична повість із часів Володимира Великого у двох томах "Ідоли падуть”». Вона була своєрідним продовженням повісті «Іду на вас» 
(1918), оскільки пов’язувалася з останньою багатьма ідеями і персонажами, і разом склали «белетризовану хроніку княжої доби» (Н. Мафтин). Ю. Опільський ще раз підтвердив думку: «Наскільки органічно обрана форма відповідає особливостям життєвого матеріалу (тобто темі), настільки глибоко вона (форма) здатна виразити його» [Клочек 1989: 113.]. У творах прозаїка гармонійно поєдналися художнє бачення історичної дійсності з відповідною системою зображальних засобів. Поетика історичної прози Ю. Опільського досить своєрідна, що виявилось у сполученні літературних прийомів белетристичної традиції з свіжими композиційними знахідками.

За насиченістю ситуаціями і пригодами, об'ємністю їх осягнення повість «Ідоли падуть» близька до роману. Про тривалу працю над твором свідчить титульна сторінка рукопису повісті «Хрести й ідоли», датована 1921 роком. У результаті - глибоко продумана, струнка сюжетно-композиційна організація, чітко окреслений конфлікт, гармонійне поєднання і пропорційність композиційних конструкцій. «Завжди, як вправний оператор відчував єдність і взаємини своӥх героїв з довкружжям, майстерно будував композицію, чергуючи описи, оповідь, згадки, монологи, проймаючи все ие світовідчуттям персонажа і свідомістю епічного автора» [Гром'як 1997: 171], - зазначає Р. Гром'як. Сюжет повісті, динамічний і гострий, містить рухливий малюнок подій.

Ю. Опільський - письменник-аналітик, що намагався проникнути до найглибших шарів народного буття, осягнути приховані його основи, розкрити докорінні протиріччя національного життя: від історичних битв до руйнування сімейних зв'язків, від складних суспільних конфліктів до роздвоєння людської свідомості. Досліджуючи проблему «людина і суспільство», митець уміло поєднав площини життя героя і народу. Реалістична картина тогочасної дійсності подана у всій повноті і цілісності завдяки авторським розповідям про роди Збраничів, Козняків, Олешичів, про взаємини князя з варягами. У XIV розділі «Земське та дружинне боярство» 
порівнюються дві верстви населення Київської Русі, їх ставлення до вістки про хрещення Володимира. Такий художній прийом сприяє глибокому розкриттю соціальної картини світу у розрізі, поєднанню різних аспектів життя. Детальні описи середовища, в якому відбувалися визначні і трагічні події, здійснювалися небезпечні походи і часом необачні вчинки, виношувались підступні плани і задуми, доповнюються описом внутрішнього світу персонажів.

Автор-аналітик розкриває психологічний характер епохи, демонструючи, як люди реагують і відгукуються на події життя, розкриваючи їх справжню сутність у зламних ситуаціях. Вдосконалюючи прийоми психологічного аналізу, він моделює складні психологічні стани персонажів (сумніви, вагання, душевну боротьбу). Розлогі портретні замальовки набувають динамічнопсихологічного забарвлення. Наприклад, Володимир «не своєю поставою притягав увагу, а поглядом великих синіх очей та гарними суворими рисами. Вони нагадували лице Святополка в будові вилиці та носа. Чоло мав високе, а повні уста проявляли якусь м'якість, незнану зовсім великому батькові Володимира. Густий вус закривав частинно губи і спадав по обох боках, надаючи поваги усій появі володаря» [Опільський 1989: 150]. Перед читачем окреслюється образ сильного і мудрого князя, мужнього воїна, впевненої у собі людини 3 «дивним вогнем» в очах. Бесіди інока Олексія 3 Володимиром виконують у структурі твору важливу сюжетнокомпозиційну функцію: автор психологічно мотивує рішення князя, який намагається проникнути в суть християнства, прийняти його душею. 3 цього моменту Володимир діє впевнено і послідовно, бо «почув себе чимось більшим, як звичайним господарем, який наказує слугам, почув себе заступником бога» [Опільський 1989: 205].

В історичній прозі Ю. Опільського домінує політичний конфлікт, але завжди, крім зовнішнього, динамічно розгортається і внутрішній - особистісний, «який розгалужується на своєрідні мікроконфлікти і в атмосфері якого живуть персонажі» [Дзюрман 2002: 11]. Це дозволяє говорити про «протистояння моральних 
альтернатив, що визначають лінію поведінки персонажів» (М. Ільницький). Так, образ героя поглиблює бінарна опозиція Володимир - Свен Герюльфсон. Вони є «психологічними двійниками, які борються між собою за ідеали, щзо взаємно виключаються» [Вервес 1983: 197]. Своєрідний «двобій» між ними допомагає простежити їх сильні і слабкі риси характеру, тому що у цій боротьбі найвища ставка - життя. Напруга досягає апогею, коли автор зводить Володимира і Свена віч-на-віч у фіналі твору. Князь у мареві, в інтуїтивному передчутті усвідомлює: «Перед ним тут у поросі, крові та гнилі лежить минуле, пережите, погане, а нове, видане, незбагненне виростає йому у душі» [Опільський 1989: 333]. Сприятливі обставини (перемога над візантійським полководцем Вардою Фоком у 987 році, здобуття Корсуня, одруження 3 царівною Анною, розкриття змови внутрішніх ворогів) сформували серед народу враження, що в хід подій втрутились надприродні сили. Письменник переконує, що хрещення Русі - найвагоміший здобуток князя Володимира, його вершинне діяння: «Тріумфатор, єдиновладний володар величезної держави, в авреолі непереможного «воїтеля», під моральним прапором иісарів Другого Риму, він міг наважстися привести свій народ до хреста» [ПолонськаВасиленко 1993: 116].

Сюжетні розгалуження Свен - Мирослава, вбивство Свеном сина Козняка характеризують лицемірство, жорстокість, облудність варяга і чіткіше відтінюють душевне багатство і моральну перевагу Володимира. Вони поглиблюють морально-етичний конфлікт твору, допомагають об'ємно дослідити зовнішнє і внутрішнє життя персонажів не тільки першого, але й другого планів. Кожен 3 них самоцінний - його характер «розкручується» в глибину. Досить об’ємно і яскраво змальовані Станко Збранич, інок Олексій Олешич, грек Анастас. Вони сугестують гостроактуальні смисли. Цими прийомами творення образів персонажів Ю. Опільський йде шляхом У. Самчука, який аналізував індивідуальне буття людини в об'єктивному і суб’єктивному планах, прагнучи якнайповніше 
осягнути багатство іiі характеру. Множина героїв у романах Ю. Опільського визначається необхідністю всебічного розкриття кожного головного образу. Життєва правда другорядних персонажів - у їх індивідуальній конкретності, коли кілька виразних ознак, деталей дозволяють проникнути в суть образу. Тому часто герої другого плану стають символічним уособленням кращих рис українського народу, яскравими національними характерами (наприклад, Мирослава, Олексій Олешич та ін.). Митець окреслив типове «через пошук того одиничного й особливого, яке стає достатньою мірою і репрезентативним» [Левчук 1997: 168].

Історичні повісті «Іду на вас» (1918) та «Ідоли падуть» (1927) Ю. Опільського за історіософською концепцією та ідейним наповненням належать «до дискурсу галищького історико-белетристичного метатексту» [Мафтин 2008: 111]. Ці «мислячі історичні твори» (Р. Іваничук) засвідчили еволюцію історичної прози 20-30-х років: аналітизм, згущений інформаційний зміст, філософські узагальнення, панорамність, концентричний тип сюжету, тип «благородного» героя, фрагментарне моделювання головного персонажа, інтервентний психологічний аналіз (сповідальні монологи, авторські коментарі, персонажна фокалізація, «чуже слово» у мовленні суб“єкта, межові ситуації), екстремальний хронотоп, взаємодія концептуального і перцептуального часопросторів «розширили» межі художньо-історичного різновиду історичної романістики (С. Андрусів), яка продовжувала традиції «Чорної ради» М. Куліша. Ю. Опільський, дбаючи про «динамічність сюжету, прагнув дати ширшу панораму життя, де б герої не тільки здійснювали вчинки, а й осмислювали свій час і себе в ньому» [Ільницький 1989: 92].

\section{БІБЛІОГРАФІЯ}

Вервес 1983 - Вервес Г. В інтернаціональних літературних зв'язках: питання контексту / Г. Вервес. - К: Дніпро, 1983. - 385 с.

Гром'як 1997 - Гром'як Р. Історична проза Юліана Опільського / Р. Гром'як //

Гром'як Р. Давнє і сучасне. Вибрані статті з літературознавства. - Тернопіль:

Лілея, 1997. - 270 с. 
Дзюрман 2002 - Дзюрман С.С. Поетика історичної прози Юліана Опільського: автореф. дис... канд. філол. наук: 10.01.01 / С.С. Дзюрман; Львів. нац. ун-т ім. І.Франка. - Львів, 2002. - 19 с.

Ільницький 1989 - Ільницький М. Історія мисляча // Ільницький М. Людина в історії: сучасний український історичний роман / М. Ільницький. - К.: Дніпро, 1989. - С. 10-148.

Ільницький 1994 - Ільницький М. Минувшина - наука на майбутнє / М. Ільницький // Опільський Ю. Твори: в 4 т. - Львів: Каменяр, 1994. - Т. 1. - С. 3-16.

Клочек 1989 - Клочек Г.Д. У світлі вічних критеріїв (Про систему критеріїв оцінки літературного твору) / Г.Д. Клочек. - К.: Дніпро, 1989. - 221 с.

Левчук 1997 - Левчук Л.Т. Естетика: підручник / Л.Т. Левчук, Д.Ю. Кучерюк, В.І. Панченко; за заг. ред. Л.Т. Левчук. - К. : Вища школа, 1997. - 399 с.

Лівенко 2007 - Лівенко І. Модель світу та форми її художнього вираження в поезії Юрія Тарнавського: монографія / І. Лівенко. - Дніпропетровськ: Січ, 2007. -279 c.

Лотман 1970 - Лотман Ю.М. Структура художественного текста / Ю.М. Лотман. - М.: Искусство, 1970. - 383 с.

Мафтин 2008 - Мафтин Н. Західноукраїнська та еміграційна проза 20-30-х років XX століття: парадигма реконкісти: монографія / Н. Мафтин. - ІваноФранківськ: ВДВ ЦІТ Прикарпатського національного університету імені Василя Стефаника, 2008. - 356 с.

Опільський 1989 - Опільський Ю. Золотий лев: повісті / Ю. Опільський. - Київ: Дніпро, 1989. - 414 с.

Опільський 1994 - Опільський Ю. Твори: в 4 т. / Ю. Опільський. - Львів: Каменяр, 1994. - Т. 1. -423 с.

Полонська-Василенко 1993 - Полонська-Василенко Н. Історія України: у 2 т. / Н. Полонська-Василенко. - К.: Либідь, 1993. - Т.1. - 640 с. 